\title{
Newspaper Reporting of Whaling in Australia and Japan: A Comparative Content Analysis
}

Tets Kimura

Flinders University

\begin{abstract}
The ongoing dispute over whaling is a significant issue of conflict between Australia and Japan. It appears that the print media in each country supports the dominant opinion: anti-whaling in Australia, and pro-whaling in Japan. To investigate media perspectives, this study reviews newspaper coverage throughout a whaling season (15 December 2007 - 24 March 2008), analysing 48 articles from Australian newspapers (in English) and 51 articles from Japanese newspapers (in Japanese). Content analysis was employed to identify the characteristics of the newspaper articles. It is believed that reporting can contribute to cultural and political transparency by providing comprehensive views on the whaling issue. However, the findings here indicate that the current state of whaling reporting tends to be one-sided. This study assesses how the whaling issue is reported in both Australia and Japan, and what influences that reporting. It also focuses on Japan's kisha club (reporters' club) system to shed some light on why Japanese journalists report pro-whaling perspectives given international criticism from Australia.
\end{abstract}

\section{Keywords}

Australia-Japan relations; bilingual analysis; kisha club; media analysis; newspapers; whaling

To link to this article: http://dx.doi.org/10.21159/nv.06.07 


\section{Introduction}

Australia and Japan have established good bilateral relationships based on mutually complementary economic relations. In recent years, the two countries have also strengthened political and security cooperation, which has made them strategic partners in the Asia-Pacific region. For example, in September 2012, a weapons technology swap plan was announced between Australia and Japan, whereby Japan agreed to export its high-standard submarine technologies for use by the Australian military. ${ }^{1}$ Furthermore, when Kevin Rudd made his first visit to Japan as Prime Minister, he emphasised that 'Australia's relationship with Japan is longstanding, close and broad-based.' Even though Australia and Japan might be considered an odd couple given the historical, cultural and economic background to their relationship, ${ }^{3}$ the two countries have managed to share many of the same political and economic values, such as parliamentary democracy, advanced capitalism and pro-US international policies.

However, there are also significant differences: namely, conflicting approaches towards whaling in the two countries. Australia stopped whaling in the 1970 s due to ethical and environmental reasons, whereas Japan continues the practice in the name of science.

A cursory inspection of news reporting on the issue indicates that these public opinions are definitely reflected in the media, both in Australia and in Japan. In Australia, public discourse often perpetuates the images of 'good Australia' and 'bad Japan' when it comes to the whaling issue, just as occurred during World War II. ${ }^{4}$ The national psyche in Japan is similarly reflected in the media. Thus, guiding questions to be answered by content analysis in this paper are as follows:

1. How do newspapers in Australia and Japan report on the issue of whaling in the Southern Ocean?

2. What accounts for similarities/differences in reporting?

The simple depiction of the whaling issue in polarised terms underrates the complexity of the cultural and linguistic frameworks operating behind the reportage of the whaling issue, particularly in relation to the reasons why Japanese newspaper articles are published as they are. The examination of Japanese reporting practice, including the kisha club (reporters' club) system, to be conducted in this study will shed light on this

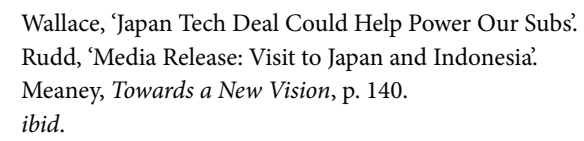


particular aspect of the issue. It should be noted that Japanese government documents issued on the whaling controversy are published in both Japanese and English. However, the problem for Australian reporters accessing Japanese information is not one of language but of access to additional privileged information provided to Japanese reporters by the government via the kisha club system.

\section{Japanese Whaling: A Review of the Literature}

In Australia, it is widely believed that Japan conducts illegal whaling in the Southern Ocean. While it is fair to say that whaling is illegal in accordance with Australia's domestic regulations, Australia's territorial claim over Antarctic waters is not universally recognised. ${ }^{5}$ Rather, it is rejected by the international agreement outlined in The Antarctic Treaty (1961), which states that the agreement 'does not recognize, dispute, or establish territorial claims and no new claims shall be asserted while the treaty is in force.' 6 Australia has been a member of the agreement since it became effective. Australia can still claim that it has a right to a part of Antarctica since it made its claim over Antarctica before the agreement was made and ratified. However, saying that is as far as Australia can go.

Japan has a much stronger legal justification to support its whaling in the Southern Ocean. The International Convention for the Regulation of Whaling (1948) allows Japan to conduct whaling for research, and this activity may include killing whales so long as the whaling contains a degree of scientific research. Furthermore, Japan is also legally permitted to use by-products from its research, such as whale meat, provided this is carried out under supervision. This is even permitted under the current Southern Ocean moratorium that started in the 1980s, and is clearly stated in Article 8 of The International Convention for the Regulation of Whaling (1946).

However, critics argue that Japan's motivation for whaling is not purely scientific. Mike Danaher claims there are four reasons why Japan wants to continue whaling in spite of international criticism: whaling is a cultural tradition, internationally legal, sustainable under an open science and harvest plan, and does not attract 'any significant domestic anti-whaling movement.7 Thus, international voices do not have a significant impact on Japanese policy-makers.

Davis, 'Taking on Japanese Whalers', p. 82

'Antarctica Law \& Government'.

Danaher, 'Why Japan Will Not Give Up Whaling', pp. 119-120. 
Atsushi Ishii and Ayako Okubo criticise Danaher's views, stating that 'he overemphasizes ... the cultural aspects of the whaling issue, ${ }^{8}$ which they suggest has often been mobilised for political ends. The notion of 'whale meat culture' is constructed to justify the current practice of 'scientific' whaling, since it helps the discourse appear 'depoliticized'.' Ishii and Okubo suggest that Anny Wong's book, The Roots of Japan's Environmental Policies, ${ }^{10}$ offers explanations that avoid reifying cultural aspects of Japanese whaling. ${ }^{11}$ Wong notes that the basis of Japan's whaling policy has remained 'unchanged in the last several decades, ${ }^{12}$ whereas the international community has shifted from a pro-whaling to an anti-whaling stance over this period. Wong emphasises that 'Japan's policy on whaling has been most strongly determined by the perspective of the Fisheries Agency' which acts as 'its chief policy maker.' ${ }^{\text {'3 }}$ Wong concludes that the Fisheries Agency's view on whaling is made 'bigger' and 'more inclusive' than economics, as its discourse on whaling expands the issue into 'one of national culture, pride, and sovereignty.' ${ }^{14}$

Keiko Hirata similarly considers the culture of Japan's domestic civil and political structures in order to explain why Japan does not adjust its whaling policy for the sake of better international relations. Because Japan's whaling policy has been formed through a structure that 'is highly centralised with strong bureaucratic leadership', the government 'has allowed virtually no room for citizens' groups to affect Japan's whaling policy.' Japanese NGOs have had some impact on other environmental issues, but antiwhaling NGOs are relatively powerless because 'the Fisheries Agency and Ministry for Agriculture, Forestry and Fisheries (MAFF) have no interest in working with them.' ${ }^{\prime 5}$

Supporting Hirata's view, the well-known Australian ethicist Peter Singer also noted that the voices of environmentalists, including those from anti-whaling movements, do not penetrate through to the general public. ${ }^{16}$ Therefore, the activists in Japan are 'clearly much more isolated than comparable groups in Western nations. ${ }^{17}$ Singer claims this is because Japanese people are identified as a member of a group, rather than in terms of their individuality. Peter Cave similarly argues that Japanese 'children first learn to be "part of the group" through 'educational trajectory, ${ }^{18}$ and the sense of group identity which shapes them will remain as they enter adulthood. ${ }^{19}$ Furthermore, Singer maintains that due to their strong sense of 'us-ness' or uchi (such as a strong sense of

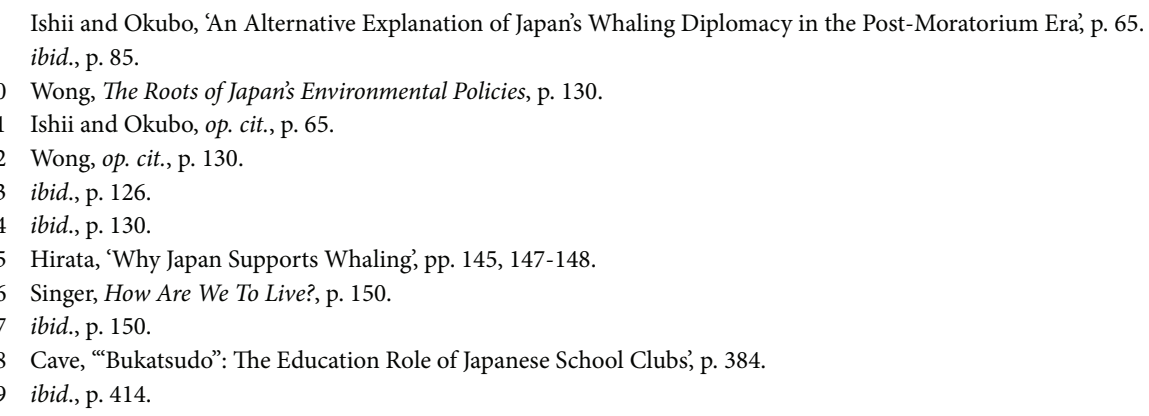


belonging to their school or company community), Japanese people are less likely to care about more abstract, global public issues such as environmental issues. After the author of this paper published an article as a freelance journalist in The Age, ${ }^{20}$ an ESL teacher who lived in Japan commented that one of his adult Japanese students said 'Japan shouldnt/couldnt [sic] do anything about the worlds [sic] environmental problems because it doesn't have resources like oil, uranium etc. ${ }^{21}$ Singer says that in some cases, Japanese people are 'both angry and embarrassed' when a family member is involved in activism around environmental issues. ${ }^{22}$ Consequently, the Japanese environmentalist perspective has a minimal effect upon Japanese society, and the Fisheries Agency (along with other officials) continues to be the main player in influencing decision-making and policy formation on the whaling issue.

Clearly, the whaling issue is not as simple as it may appear in the Australian media. To understand the problem, a comprehensive understanding of Japanese society and culture, in addition to the facts about whaling, is required. The following section shifts focus, in order to consider the background to Australia's position on whaling and the main reasons cited against Japan's whaling.

\section{Australian Anti-Whaling: A Review of the Literature}

In Australia, whaling (combined with sealing) was an important part of the colonial economy, being the biggest industry until gold mining overtook it in the 1850 s. However, by the end of the nineteenth century, the whaling industry, which produced whale oil predominantly for lamp lighting, began declining after the discovery of kerosene as a cheaper fuel source for lighting. Whale oil was no longer required as a source of fuel for lighting by the middle of the nineteenth century as it was replaced first by kerosene, and later by electricity.

By the 1970s, economic reasons were not the only factor that contributed to this decline; there were also ethical and environmental reasons. Shortly before Australia adopted an anti-whaling policy in 1979, Peter Singer made a submission to the Australian Government's Inquiry into Whaling, arguing that whaling is ethically wrong from a utilitarian perspective. ${ }^{23}$ His views have not changed since then ${ }^{24}$ and have long been used as the basis of ethical reasoning in anti-whaling perspectives. Singer has claimed that since animals are capable of suffering, there is no justification to 'draw

20 Kimura, 'Getting to Know the Japanese'.

21 'A Whaling State of Mind'.

22 Singer, op. cit., p. 150.

23 Singer, 'Why the Whale Should Live', pp. 8-9.

24 Singer, 'Hypocrisy Weakens West's Whaling Protests'. 
the boundary of our concern for the interests of others at the boundary of our own species. ${ }^{25}$ Singer calls this kind of limited moral perspective "speciesist" - a term which is intended to suggest an analogy with racism. ${ }^{26}$ Singer's ethical framework on whaling provides a compelling anti-whaling argument: if we accept the principle that animals should not be killed or made to suffer significant pain, except when there is no other way of satisfying important human needs, it follows that whaling should stop.

Singer admitted that the end of whaling could create other social problems, such as increased unemployment as a result of the demise of the whaling industry. However, he rejected this as a justifiable reason for the continuation of whaling, noting that ' $\mathrm{m}]$ oral progress has frequently required economic adjustment. ${ }^{27}$ In support of this line of argument, he cited the example of the slave trade, which was required to find other goods to ship. ${ }^{28}$

The idea of whale rights is supported not only by consequentialists such as Singer. Tom Regan develops some of Singer's ideas from a neo-Kantian perspective, arguing that whaling is universally wrong from a standpoint of absolute morality. ${ }^{29}$ Furthermore, some scientists also criticise the scientific justification used by Japan. For example, Australian scientist Nick Gales and his colleagues criticise Japan's whaling research on the basis that it is not scientific enough: 'The strongest scientific argument in favour of lethal sampling-the collection of genetic samples for determining population structure-could be conducted far more efficiently using non-lethal biopsy techniques. ${ }^{30}$ The scientists also maintain that the publication record is poor and limited for a research endeavour of this size. For these reasons, Japan's scientific whaling is regarded as 'inhumane and lacking scientific justification.' ${ }^{31}$

Both ethical and scientific theories have been adopted by environmentalist organisations such as Greenpeace, which has strong public support in Australia and other developed countries, to justify their anti-whaling activities. Ishii and Okubo note, 'the Japanese policymakers underestimated the growing political power of environmental NGOs. ${ }^{32}$ The Australian government is somewhat subdued in voicing criticism, but clearly states: 'There is no scientific justification for Japan's whale hunt in the Southern Ocean... The Government will continue to work to bring an end to whaling. ${ }^{33}$

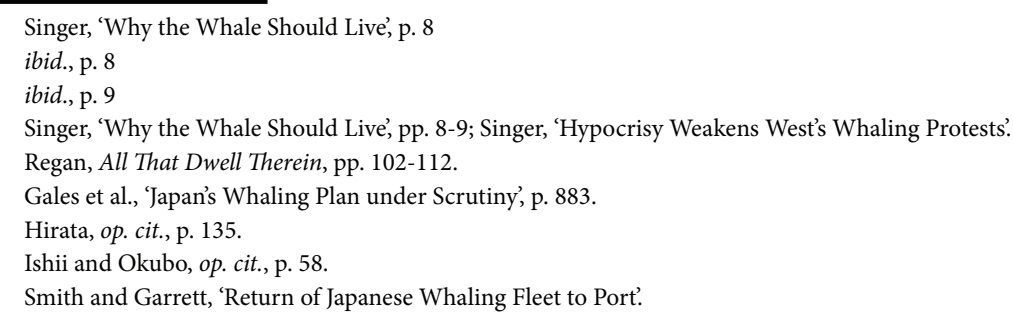


In response to continued Japanese whaling in the Southern Ocean, the Australian government launched an international legal case against scientific whaling in May 2010. The Australian situation is quite different from the political situation in Japan, where the government-oriented whaling camp sits at the centre of the debate, deploying policies for its citizens to accept virtually without question. ${ }^{34}$ Australia's justifications are based on totally different principles from those adopted by the proponents of Japanese pro-whaling perspectives. This situation is said to make it very difficult for the two countries to find common ground for reasoned debate. This explains why it is difficult for Australians to understand Japan's pro-whaling position, and vice versa.

In the field of academia, a team led by Paul Cunningham recently argued that whaling and whale conservation can coexist. ${ }^{35}$ They point out that a whaling country such as Japan can offer multiple whale-watching sites and that the industry is growing. However, this information has not influenced the views of the general public. A fundamental task of the media is to provide information to enable citizens to understand and contextualise issues that affect them. The primary purpose of this content analysis is to assess how the whaling issue is reported in both Australia and Japan, and what influences that reporting, particularly looking at the influences of Japan's kisha club on Japanese newspapers.

\section{Methodology}

In order to examine the nature of reporting on Japan's whaling in the Southern Ocean, the technique of content analysis was employed to examine sample articles drawn from Australian and Japanese newspapers. Content analysis was used to identify and analyse themes in the sample, providing an insight into differential patterns of tone, balance and news framing that tend to be employed by each country's journalists.

The analysis presented in this paper covers the whaling season in the summer of 20072008. A convoy of whaling ships left Japan on 18 November 2007 and returned on 15 April 2008, a period of 150 days. However, the whaling activity in the Southern Ocean itself only started on 15 December 2007 and ended on 24 March 2008, a period of 101 days. ${ }^{36}$ This shorter period was set as the time frame for the study.

\footnotetext{
34 Ishii and Okubo, op. cit., p. 56.

35 Cunningham et al., 'From Whaling to Whale Watching'.

36 'Dai ni ki nankyokukai geirui hokaku chōsa (JARPAII)'.
} 


\section{Source Newspapers}

To maximise the validity and generalisability of the analysis, newspapers that best reflect the current landscape of both Australian and Japanese trends were chosen.

For Australian newspapers, The Australian, a slightly right-of-centre national newspaper with headquarters in Sydney; The Age, a slightly left-of-centre daily newspaper from Melbourne; and The Advertiser, Adelaide's only daily (tabloid) were selected. The Australian and The Advertiser are owned by News Corp Australia, Australia's largest print-media conglomerate, whereas The Age is owned by Fairfax Media.

A sample of Australian articles was gathered using NewsBank. While the database does not archive all articles published, it was possible to collect a broadly representative sample of the newspaper reporting, and thus was useful for the purpose of this study.

For the Japanese counterparts, the two largest Japanese national newspapers, Asahi (slightly left-of-centre) and Yomiuri (slightly right-of-centre) were chosen. In Japan, regional newspapers similar to The Age and The Advertiser are seen as 'minor' newspapers and therefore have not been sampled.

Analysing Japanese-language articles, instead of English-language newspapers such as The Japan Times, is extremely important as Japanese is the dominant language of Japan. Analysing Japan's English-language newspapers would have produced an insufficient and inaccurate result, since the study aims to compare how dominant newspapers report whaling news in each country.

\section{The Process of Sample Collection}

It was important to ensure that search terms were consistently employed across the different language search engines. Therefore the terms were kept as simple as possible. Since the study also comprised bilingual research, care was taken to find search terms that were effectively translatable and that corresponded with an equivalent English/ Japanese word in terms of meaning and frequency of use in common discourse. ${ }^{37}$

NewsBank was used to collect Australian samples, and the search term 'whaling in the lead/first paragraph' as well as the phrase 'Southern Ocean in all text' was used to

37 Various techniques to overcome the problems on translation are argued by Eco in Mouse or Rat?. 
define the sampling strategy. Using the first term, the engine only picked up articles that had the main theme of whaling. Using the second term, the engine found articles that targeted Japan's whaling in the Southern Ocean. Non-related articles on travelling, gourmet cuisine and other general political and environmental news items were removed from the sample so that the focus related specifically to Japan's whaling activities. Letters from readers were also removed from the sample. Only first editions of articles were selected for analysis. As a result, 20 articles remained from The Australian, 13 from The Age and 15 from The Advertiser, making a total of 48 Australian articles.

An identical method was used to collect Japanese samples. ${ }^{38}$ Articles were selected for the sample if they had the word 'hogei (whaling)' in the lead/first paragraph as well as the word 'nankyoku (Antarctica or Antarctic)' in the entire article. ${ }^{39}$ Non-related articles and letters from readers were eliminated. In the Japanese sample, only first editions came up in the search. To ensure consistency of analysis across the entire sample with respect to the style of journalism under scrutiny, some extra reduction techniques were employed. For Asahi articles, non-newspaper articles were excluded because their search engine attracts items from magazines such as AERA and Shükan Asahi. These are not supplement magazines but external publications which do not belong to the newspaper itself. Additionally, all Asahi articles that appeared in local (chiiki) pages were excluded, since those articles only appear in a limited area of Japan, usually within a particular prefecture. The focus of these articles is not concerned with Japan's whaling in the Southern Ocean, but rather with regional news stories about local whaling communities. In addition, two articles only showing the results of surveys were excluded from the analysis because they do not constitute news articles.

For Yomiuri articles, photo captions that were automatically classified as articles were excluded. To maintain consistency with the reduction process used for Asahi articles, articles that were published in regional (non-Tokyo) editions were also excluded. Lastly, articles from both Asahi and Yomiuri that are specially written for children for the purpose of education were removed. These kinds of articles do not appear in Australian newspapers, and are not a part of the Australian print media news culture. Articles aimed at children were considered beyond the scope of analysis in this study, which sought to maintain focus on mainstream media and its journalistic impact upon the awareness of the general public. In total, 25 articles remained from Asahi, and 26 from Yomiuri, making a total of 51 articles. Thus, the total number of articles drawn from Australia and Japan for analysis was 99.

38 The author acknowledges the contribution of Ms Tomomi Kimura and Associate Professor Jiro Morioka in gathering Japanese newspaper articles.

39 The direct translation of 'Southern Ocean' is 'nanpyoyō'; however, the word 'nankyoku-kai (Antarctic Sea)' is more common, being the term officially designated by Japan's Geographical Survey Institute (GSI), under the Ministry of Land, Infrastructure, Transport and Tourism (MLIT). Major Japanese media including Asahi and Yomiuri use 'nankyoku-kai' rather than 'nanpyōyō'. 


\section{Coding}

The data were examined using the following four codes: objectivity, balance, angle and overall tone. $^{40}$

Firstly, it was important to identify the degree of objectivity: whether the reporting in the articles provided fact-based 'hard news', or 'soft news' such as opinion or editorial pieces. Hard news stories carry only factual information, and thus the tone of the language is neutral and the information is objectively presented. On the other hand, soft news items tend to offer more description and context, and often also carry subjective opinions, including moral judgements. Thus, emotive language is sometimes used to express those opinions.

The articles were coded as 'hard' or 'soft' according to whether the journalist used techniques of subjective expression. Firstly, articles that were automatically classified as 'opinion' or 'editorial' by NewsBank were classified as soft. Similarly, Japanese-language articles that were classified in databases as opinion articles by the use of words such as 'shasetsu (editorial comment)', 'kaisetsu (exposition)', and 'shiten (perspective)' were also identified as soft. The remaining articles were then examined by hand and coded as soft or hard according to the language used in the reporting.

Following the initial coding, the hard news articles were examined for evidence of manifest content corresponding to the analytic category of journalistic balance. Soft articles were excluded from this analysis, as opinion pieces were not necessarily expected to be balanced. To determine the balance of relative perspective in each hard news article, every individual or organisation quoted or cited in the article was counted. For the purpose of this study, quotations and citations were each counted individually rather than categorised by organisation. For example, if three people from Greenpeace and one person from the Japanese government were quoted, by counting each individual the analysis here would show that there was more weight given to the Greenpeace perspective than there was to the Japanese government. ${ }^{41}$

References to people in general, such as 'Australians say no to Japan's whaling,' were not counted. This is because 'Australians' were not quoted or cited in a factual way by journalists. Rather, this represents a general assumption of the dominant view. However, phrases such as 'Australia claims' were included, since this phrase was commonly used to indicate the perspective or views of the Australian government. Similarly, when

\footnotetext{
40 An appendix to this paper showing the schedule of analysis is available at http://www.flinders.edu.au/sabs/sis/research/tetskimura.cfm.

41 If only organisations were counted, the result would indicate two sources overall (Greenpeace and the Japanese government), thus the article would seem more balanced than it might actually be.
} 
statements were attributed to an organisation (for example, a government or Greenpeace), they were counted even though a particular individual was not mentioned. ${ }^{42}$

Another exclusion from counting was when newspapers used information from another media source, such as when Japanese media reported that the Australian Broadcasting Corporation quoted a source in Australia. In such cases, the initial source of information was counted. Subsequently, sources of information were labelled with respect to their alignment in the whaling debate, allowing the identification of material sourced from a pro- or anti-whaling individual, group or organisation, or from a neutral body such as police or customs officials who might not have an opinion about whether or not whaling was justified. Thus, an additional investigation relating to journalistic balance was undertaken in order to decide whether the article incorporated the voice of the adversary' - that is, whether evidence of a Japanese pro-whaling perspective was noted in an Australian article, and vice versa.

Thirdly, within the broad topic of Japan's Southern Ocean whaling, a range of specific 'angles' which indicate topic emphasis were identified. Each article was categorised with respect to the topic that was emphasised in the article, which in turn suggested what triggered the journalist to write that article. The 'angle' defines the readers' first impression of why the article was written. The following codes were used:

- Australian politics: Australian domestic political issues, such as policy and ideas existing within the government, or related claims made by the opposition.

- Japanese politics: The same as above (in the Australian case) but in Japanese politics.

- NZ politics: The same as above but in New Zealand politics. ${ }^{43}$

- International politics: The emphasis was related to international political issues such as a talk, debate or political negotiation between the Australian and Japanese governments.

- Court case: The benchmark court case that claimed Japan's whaling in the Southern Ocean was illegal. ${ }^{44}$

42 If an individual was subsequently identified then the source was not counted twice.

43 The (anti-)whaling issue in New Zealand is not a relevant topic to this study, but since some Australian newspapers reported political stories from New Zealand (which is also a strong anti-whaling country), this category was created.

44 The claim was made by the Humane Society International (HSI) according to Australian domestic law, and a Federal Court judge announced the decision on 15 January 2008 in favour of HSI. However, the decision had no practical effects on Japan's whaling activities because Australia's territorial claim on the Southern Ocean is not internationally recognised. 
- Protests: The emphasis was primarily related to anti-whaling protest movements-activities usually conducted by Greenpeace and/or Sea Shepherd.

- Other: None of the above, or when plural topic emphases were given equal weight in a story with mixed topics.

Finally, a latent coding technique was employed to determine the overall tone of the article and the underlying opinions expressed. Firstly, articles were judged to be antiwhaling if they predominantly contained content such as an emphasis on animal rights, environmental issues, criticism of unnecessary slaughter, criticism of scientific research, and heavy emphasis on anti-whaling activists' opinions. Secondly, articles were judged to be pro-whaling if they predominantly contained content such as an emphasis on the value of the scientific research, the idea that scientific whaling is legal, and claims about the cultural value of whaling. Thirdly, articles were judged to be neutral if they contained a balance of both perspectives more or less evenly.

\section{Findings}

\section{Content Coding 1: Objectivity}

The vast majority of articles from both Australia (85\%) and Japan (75\%) were classified as hard, and the remaining were classified as soft (see Chart 1).

\section{Chart 1.}

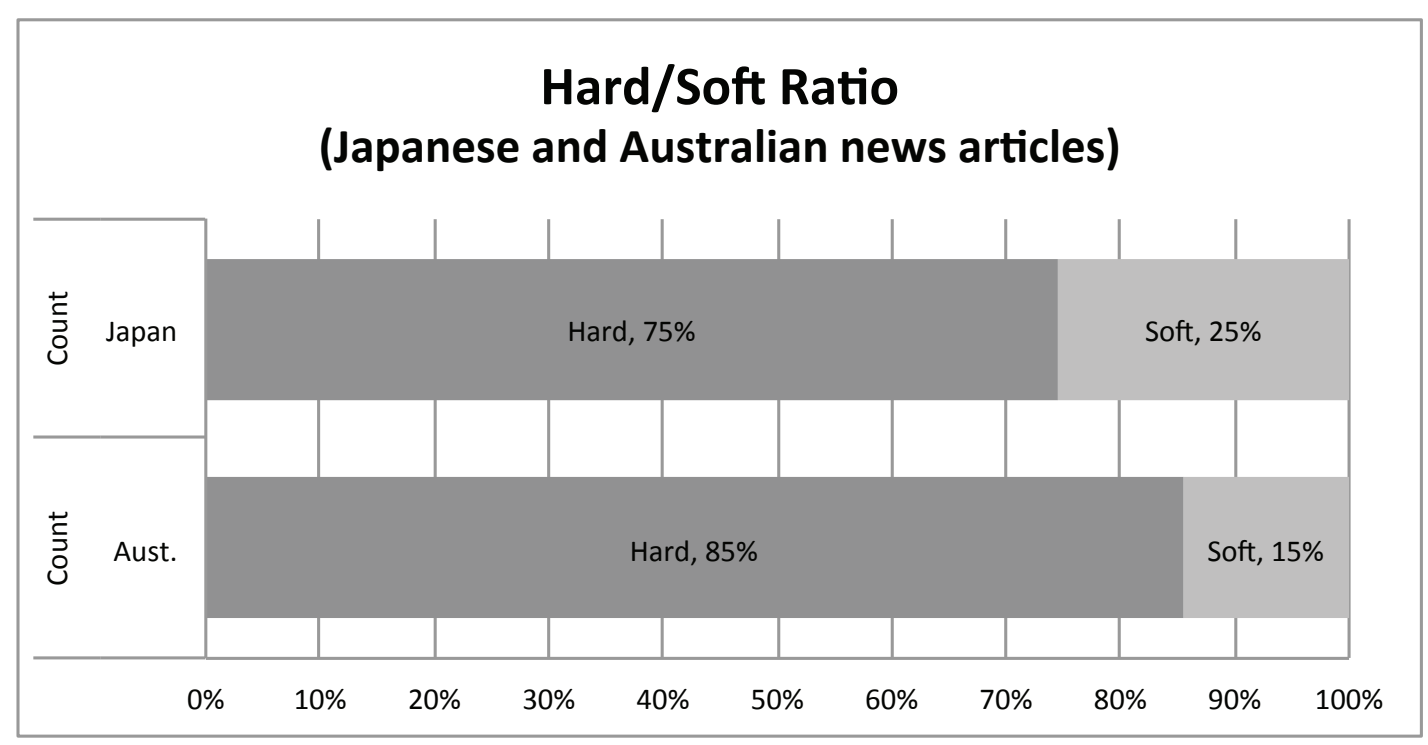




\section{Content Coding 2: Balance}

The difference between Australian and Japanese newspapers was clear (see Chart 2). Seventy percent of the speaking power found in Australian newspapers constituted voices from an anti-whaling perspective, whereas only $19 \%$ of the voices expressed a pro-whaling perspective. On the other hand, a different trend was found in the Japanese newspaper articles. Fifty-seven percent of the speaking power found in Japanese newspapers constituted voices expressing a pro-whaling perspective, whereas $34 \%$ of the voices gave an anti-whaling perspective.

\section{Chart 2.}

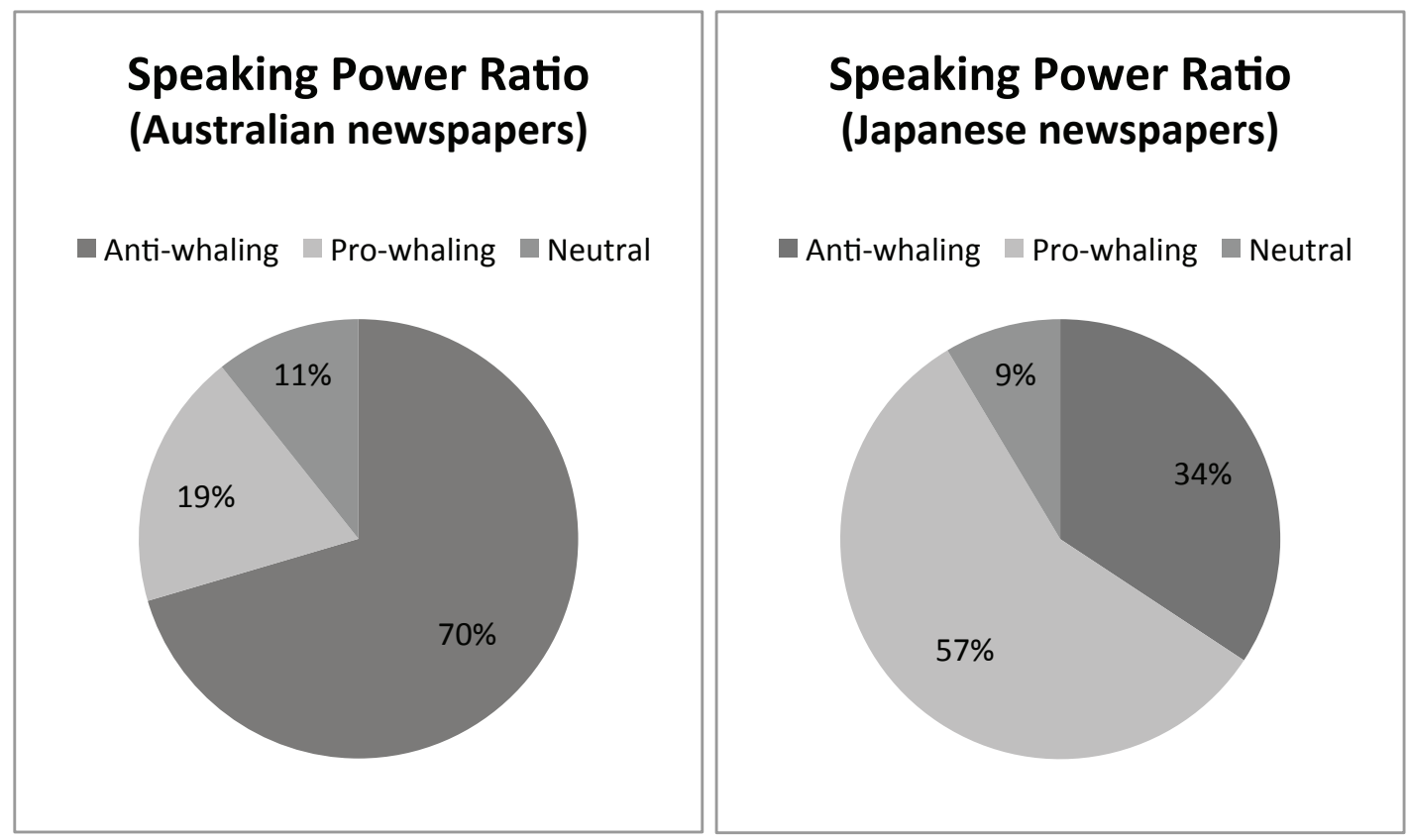

This might be an indication that Japanese journalists are slightly more willing to broadcast the voice of the 'adversary'. It is interesting to note that as much as Japanese officials strongly believe in their strong pro-whaling stance, the media in Japan does not necessarily have a narrow point of view. The results of this analysis suggest that Australian journalists are more conservative in aligning their views with the dominant beliefs of their society than Japanese journalists. Indeed, Ian McArthur, in 'Media Portrayal of the Cultural Relationship between Australia and Japan', says 'Little of Japan's cultural and historical justification for its intention to resume whaling is mentioned in the Australian reports which have focused on emotional demands that Japanese vessels leave "our" ocean."

45 McArthur, 'Media Portrayal of the Cultural Relationship between Australia and Japan', p. 585. 
Another notable indication from this analysis is that the number of quotations and citations that appear per article were quite different between the two countries. On average, 3.88 quotations/citations were found per Australian newspaper article (2.73 anti-whaling, 0.73 pro-whaling and 0.41 neutral), whereas only 1.83 quotations/ citations were found in Japanese articles (0.63 anti-whaling, 1.05 pro-whaling and 0.15 neutral; see Chart 3).

\section{Chart 3.}

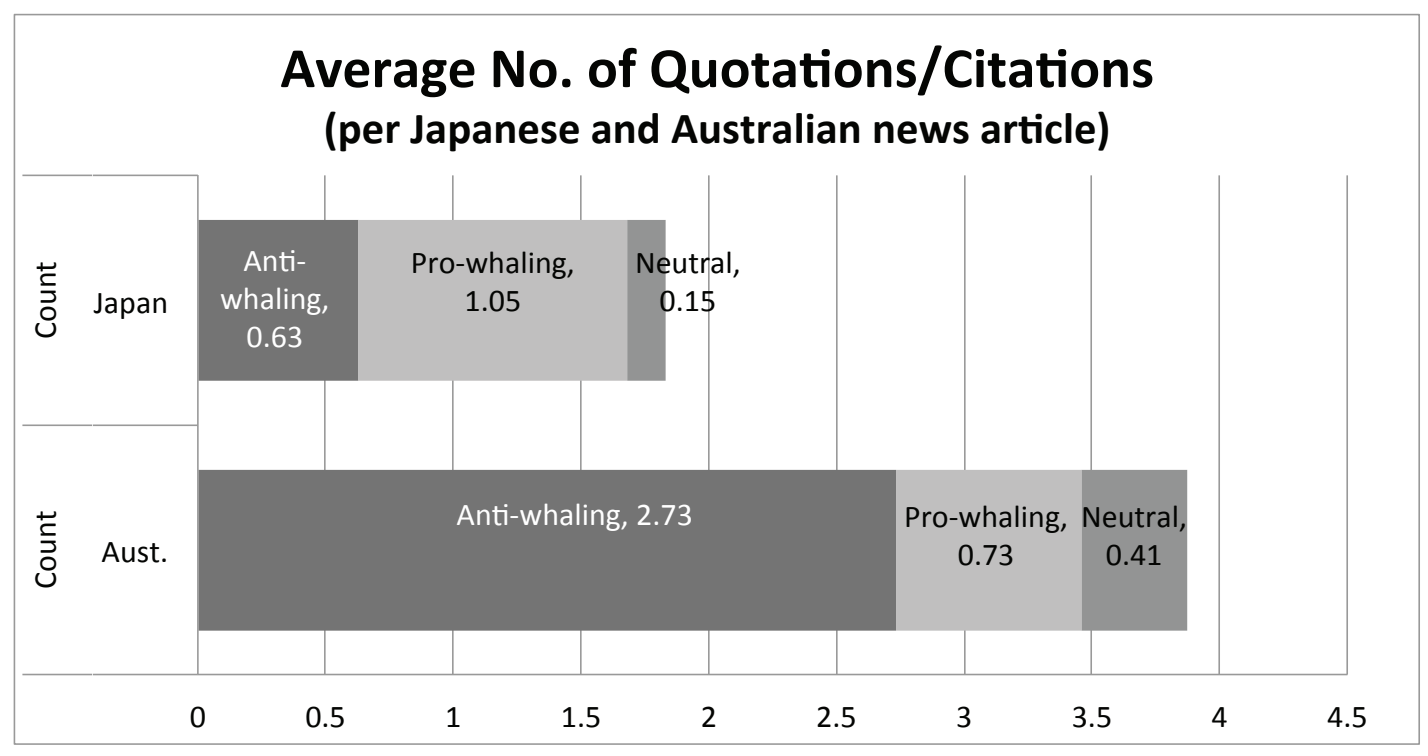

This is likely to be because the style of journalistic writing is different between Australia and Japan. In Australia, an article can be written more comprehensively, often combining plural viewpoints in the one article. On the other hand, in Japan, two separate articles with different viewpoints were found to be written about one event. For example, after the court decision against the Japanese whalers was made by the Australian federal judge on 15 January 2008, Yomiuri published two separate articles the following day. In one article by the Yomiuri's Sydney correspondent, the journalist included the viewpoints of the Court, HSI, and the Japanese government. ${ }^{46}$ In the other article that was published later on the same day, only the voice of Machimura Nobutaka, the Chief Cabinet Secretary, was included (the journalist was unspecified, but it is assumed that the article was written in Tokyo where the Chief Cabinet Secretary has regular press conferences). ${ }^{47}$ This finding could be due to the fact that major Japanese newspaper companies publish two editions in a day-the main morning edition (chōkan) and the smaller evening edition ( $y \bar{u} k a n)$.

46 Arai, 'Nihon no chōsa hogeisen ni sōgyō teishi meirei'.

47 'Gō no hogeisen sōgyō teishi meirei'. 
However, in Australia, these articles would most likely be combined into one longer and more comprehensive piece, a point supported by the fact that among the selected articles for study, no Australian paper had a second or additional article on this issue, preferring to contain all the information in single, more complex and multi-faceted articles.

\section{Voice of the Adversary}

Just over $60 \%$ of hard articles from Australia (63\%) and Japan (61\%) carried a voice from the adversary that opposed the main viewpoint. The remaining articles did not (see Chart 4).

\section{Chart 4.}

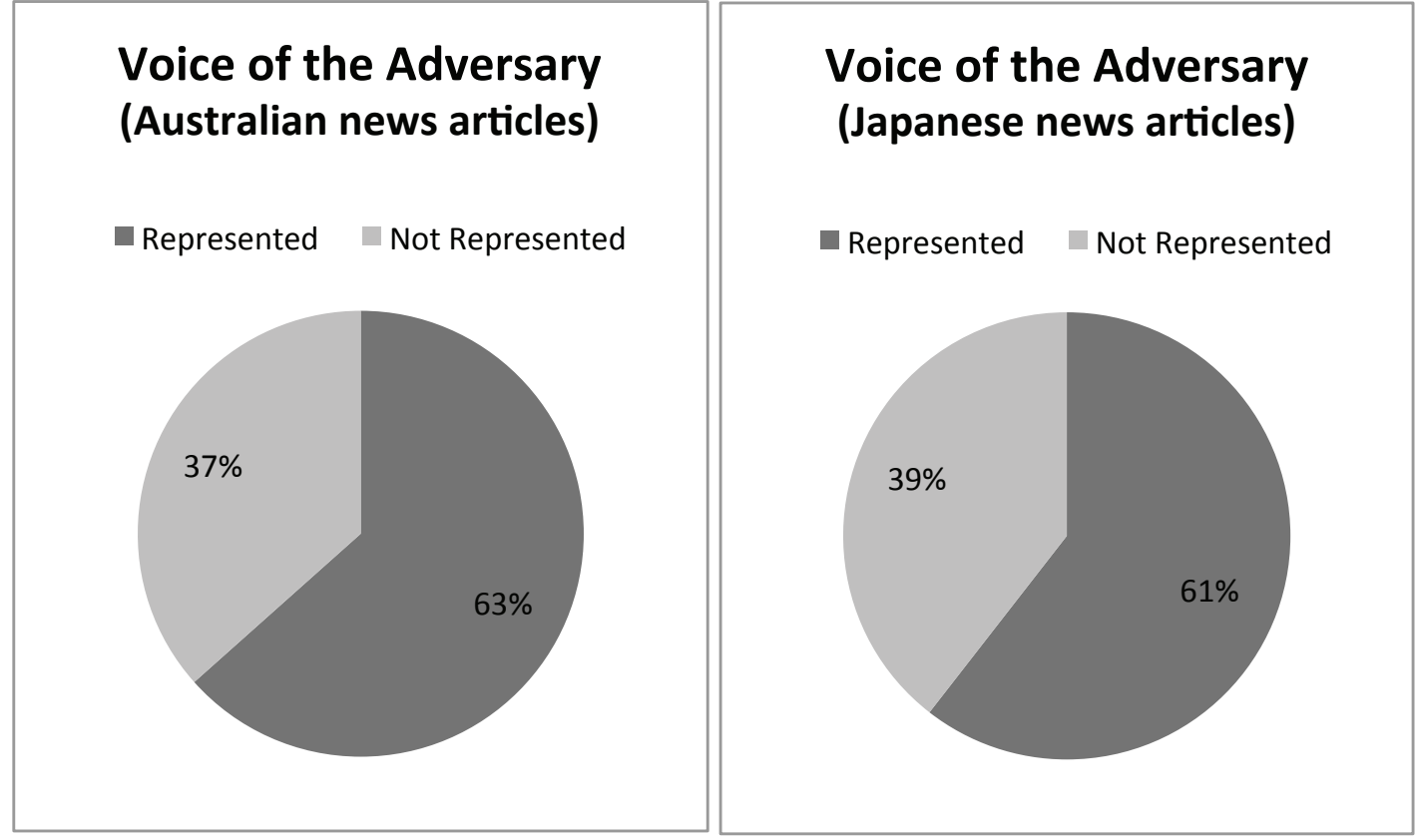

As the difference between Australia and Japan was only 2\%, it could be said that both Australian and Japanese journalists equally record a voice from their respective national adversary. This could indicate that, as much as Australian journalists tend to use a higher proportion of quotations/citations representing dominant views from the Australian side, or as much as Japanese journalists are reluctant to gather more information, journalists both in Australia and Japan are equally serious about acknowledging the voice of the adversary in their articles. 


\section{Content Coding 3: Angle}

The angles, which suggest topic emphasis of articles (thus suggesting what triggered the journalist to report), were examined. The results show that $42 \%$ of articles from Australia and $60 \%$ of articles from Japan carried an angle related to protests by environmentalist groups such as Greenpeace and Sea Shepherd (see Chart 5).

\section{Chart 5.}

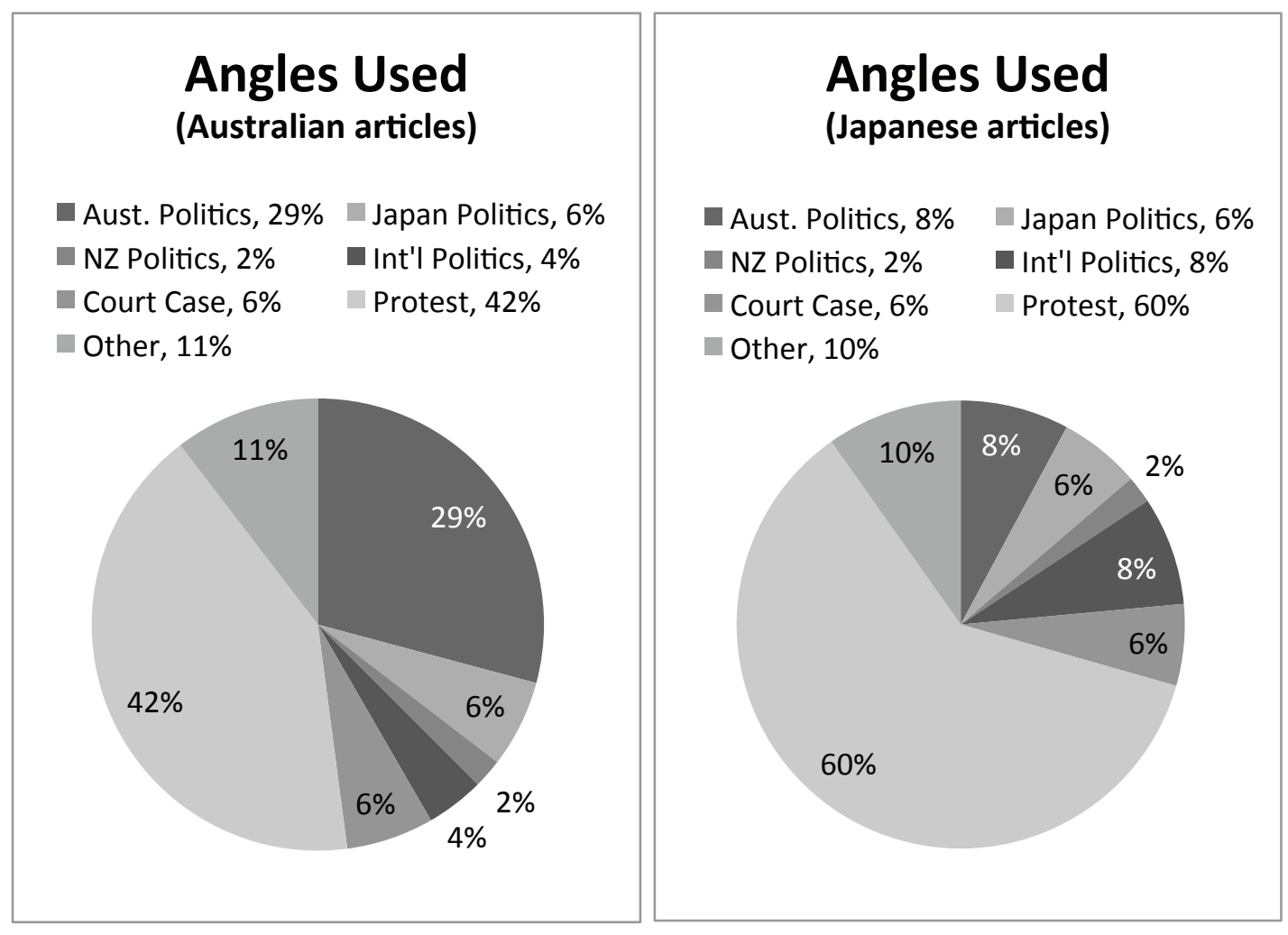

The second-biggest angle in all articles in Australia was Australian domestic politics (29\%), whereas in Japan, the second-biggest angle was not Japanese domestic politics but Australian politics and international politics ( $8 \%$ each). In Japanese newspapers, Japanese politics was only the fourth-biggest angle (6\%). This reinforces the aforementioned claim that whaling is not seen as a major issue in Japan. ${ }^{48}$

Among the Australian soft articles, the biggest angle was 'other' (observed in 67\% of the soft The Age articles and 75\% of The Advertiser). This was due to the fact that they all carried more than one angle. Australian soft articles are written more comprehensively in comparison to Japanese soft articles. On the other hand, the

48 Kimura, 'Lost in Translation'; Kimura, 'Why Japan is Deaf to Whaling Protests'. 
biggest angle among the Japanese soft articles was still protest (37\% of all Asahi soft articles and $80 \%$ of Yomiuri soft articles had a protest angle). Only 38\% of all 'soft' articles in Asahi and 20\% of Yomiuri had multiple angles, in comparison to 67\% in The Age and 75\% in The Advertiser. This shows that writing opinion-style articles with comprehensive view points is an uncommon practice in Japan.

\section{Content Coding 4: Tone}

Of the entire 99 articles, irrespective of whether the article was hard or soft, Australian articles were most likely to carry an anti-whaling tone, and Japanese articles tended to carry the opposite tone (see Chart 6).

\section{Chart 6.}

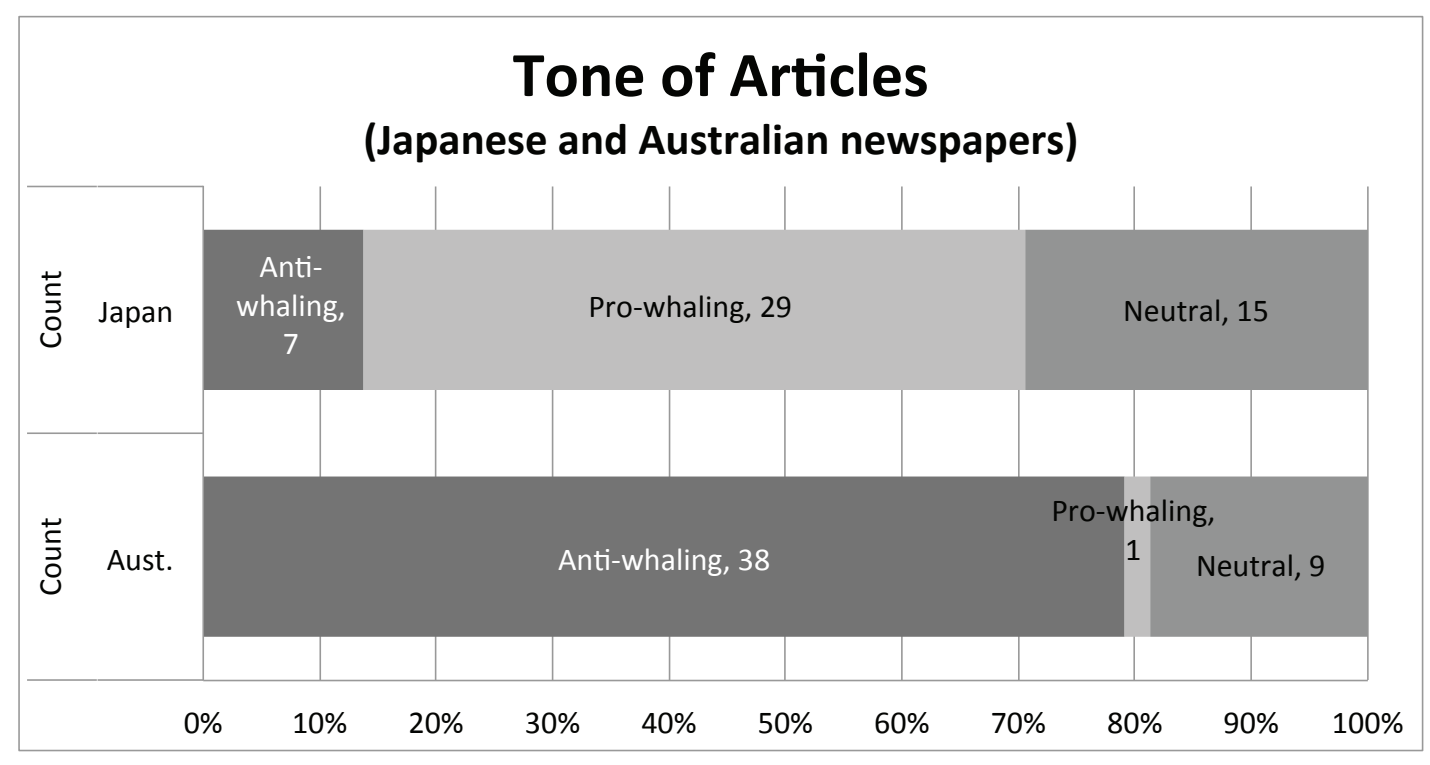

Japanese newspapers seem comparatively more supportive of, or receptive towards, international perspectives. This suggests that Japanese journalists may realise the importance of the international voice of anti-whaling. From Japan, six hard articles (three each from Asahi and Yomiuri) were classified as having an overall anti-whaling tone. ${ }^{49}$ A noticeable point is that one soft article from Asahi was written with an overall anti-whaling tone, while no other soft articles from other newspapers were written from their adversary's viewpoint. The Asahi article, dated 31 January 2008, was written by Jun Hoshikawa, the head of Greenpeace Japan. ${ }^{50}$ This indicates that some Japanese journalists

\footnotetext{
49 Arai, 'Hogei no shōko shūshū'; Arai, 'Nankyokukai deno nihon no hogei'; Arai, 'Nihon no hogei'; Sugii, 'Chōsa hogei shūgeki niwa hinan; Sugii, 'Hogeisen, NZ kinkai e’; Sugii, 'Gō, nihon no chōsa hogei kanshi'.

50 Hoshikawa, '(Watashi no shiten waido) Chōsa hogei'.
} 
or editors, especially at Asahi, may realise the significance of the international antiwhaling stance. In addition to findings about overall tone, findings on representation of the voice of the adversary shows that Asahi had a higher percentage (65\%) in comparison with Yomiuri (57\%). In Japan, Asahi is regarded as a liberal newspaper, whereas Yomiuri is regarded as conservative. These findings support this.

In Australia, on the other hand, only one article (a 'hard' article from The Advertiser ${ }^{51}$ ) was classified as having an overall pro-whaling tone. However, this does not necessarily mean that Australian journalists did not record the voice of the adversary, as findings related to the balance of sources clearly demonstrate. This is evidence for a selective writing style employed in Australian journalism. Even though news stories in Australian papers are often more comprehensively written, carrying viewpoints of both anti- and pro-whaling voices, their overall tone may remain in favour of anti-whaling perspectives because this is the dominant belief in Australia. Australian journalists appear to be acknowledging the position of the adversary, but still downplay its validity. John Hartley argues that conflict is 'the bread and butter of news', but for that to be a worthy news item, 'a prior assumption of the "underlying" consensus to which they are a threat must be at work. ${ }^{32}$ In the whaling debate, Australians holds this prior assumption.

\section{Discussion}

Although Australia and Japan have stood at different positions in the whaling debate, and despite the differences in newspaper articles, the findings show that many similarities exist. For example, looking at the balance of articles both in Australia and Japan, the speaking power ratio for each country (summarised in Chart 2) was found to be in line with the two governments' positions and public opinion. Additionally, the majority of articles from both countries were found to be written from the angle of protest activities. Furthermore, the overall tone of the articles reflects the dominant belief in each country with respect to whaling. This trend is particularly strong in 'soft' articles-only one Asahi article stood against the dominant belief.

Thus, it is fair to conclude that newspapers in both Australia and Japan are conformist about the whaling issue, in that they report in a manner aligned with their national perspective. This could escalate the whaling dispute. As discussed in the literature review, the two countries continue to go head-to-head on the whaling issue, with no sign of this abating. 
In the same way that justifications for and moral beliefs on the whaling issue in Australia and Japan are in contrast, ${ }^{53}$ the style of newspaper writing on the issue appears to be different in each country. Considering language and cultural differences, it is not difficult to imagine that different countries have different journalistic traditions and practices. For example, on average more than twice as many quotations/citations were found in Australian newspapers in comparison to those of Japan (see Chart 3). One reason for this could be that Australian articles are generally longer.

However, in Australia, even though articles are physically longer than their Japanese counterparts, the results of this study from Codings 2 (balance) and 4 (tone) reveal that Japanese reporting tends to contain more viewpoints in comparison to that of Australia. As a result, one could conclude that the Australian general public might have less chance to be informed of a range of cultural and political views through newspapers. In Japan, there is a strong connection between the media and government. According to Roberto Herrscher, Japanese journalists 'treat their authorities with reverence... not by the imposition of a Western-style universal code. ${ }^{34}$

Japan is said to be unique in that it is the most developed country in Asia but belongs to neither the West nor its neighbour Asia. Samuel Huntington states that Japan is the only country that does not share a civilisation with any other country. ${ }^{55}$ The uniqueness may be described as the 'Japan System' according to Karel van Wolferen:

It is crucial to distinguish Japan from other nations with governments that are besieged by special interest groups or that cannot make up their minds because of interdepartmental disputes. We are not dealing with lobbies but with a structural phenomenon not encompassed by the categories of accepted political theory. A hierarchy, or rather a complex of overlapping hierarchies, is maintained, but it has no top. There is no supreme institution with ultimate jurisdiction over the others. ${ }^{56}$

Van Wolferen also says, 'it is not only impossible to locate a center, it is also not possible to separate the realms of public and private business. ${ }^{57}$ Ishii and Okubo use Van Wolferen's 'Japanese System' model to explain that Japan is 'a state with central organs of government which can both recognize what is good for the country and bear ultimate

\footnotetext{
53 For discussion of justifications and beliefs, see Kimura, 'Gōshūjin wa naze hogei ni hantai suruka'; Kimura, 'Seifu ga hogei haishi motome ICJ ni teiso'; Kimura, 'No Legal Enforcement Can Stop Japan's Whaling'; Kimura, 'New Strategy Needed for Elusive Quarry'; Kimura, 'A Cool Head Required to Save the World's Whales'; Kimura, 'Getting to Know the Japanese'.

54 Herrscher, 'A Universal Code of Journalism Ethics', pp. 286-287.

55 Huntington, The Clash of Civilizations and the Remaking of World Order.

56 van Wolferen, 'The Japan Problem', p. 289.

57 ibid., p. 294.
} 
responsibility for national decision-making. ${ }^{58}$ This explains why Kumiko Murata has also acknowledged that Japanese editorials on the whaling issue are written as if the writer is reporting an official statement on behalf of the Japanese government. ${ }^{59}$ Thus, in the current environment, Japanese media only have limited options, and act as if they are public relations agencies for their government.

Another point to consider is that the lack of freedom in Japanese media is a reflection of Japanese society in general, in comparison to Western countries. Ben Hills, former Tokyo correspondent for The Age and The Sydney Morning Herald, referred to the 'press restraints' and 'restriction of freedom of speech' that exist within Japan, after his book criticising the Japanese monarchy system was once refused publication in Japan. ${ }^{60}$

Furthermore, Japan offers journalists access to the kisha club (reporters' club), where they receive news information from official authorities, but access to the club is typically limited to Japanese journalists and corporate media. What can be called the 'elite press $^{3}{ }^{1}$ are the only ones who have access to the kisha club. Ivan Hall claims, 'Foreign correspondents are held to be unfit for club participation because they are said to lack the requisite language skills. ${ }^{62}$ It is also said that 'Western (and other Asian) newspeople cannot be trusted to maintain club confidences, ${ }^{63}$ especially at kondan (unofficial gatherings). Hall implies that Japanese reporters occasionally admit that they simply do not feel comfortable with foreigners.

In May 2009, The Japanese Supreme Court rejected a final appeal for access to the club by a freelance journalist, Hajime Imai. ${ }^{64}$ The Japanese government at the time of writing, led by the Democratic Party of Japan, has only made minor changes to the kisha club since it gained power in 2009, even though it 'came to power pledging to abolish the kisha club system and open up press conferences to foreigners, freelancers and new media.65

According to Greenpeace Japan, a non-kisha journalist was refused entry to the media room provided by the Japanese government at the annual meetings for the International Whaling Commission in Morocco in June 2010. Apart from club members, only one Japanese freelance journalist was permitted (but only on the final day) to enter the media room after relentless pressure. A similar incident was reported by Reporters Without Borders in June 2012. In a visit to the Fukushima Daiichi nuclear power plant (which was

\footnotetext{
58 Ishii and Okubo, op. cit., p. 68.

59 Murata, 'Pro- and Anti-whaling Discourses in British and Japanese Newspaper Reports in Comparison', p. 752.

60 Kimura, 'Nihon seifu no atsuryoku ni Kōdansha wa kusshita'.

61 Hall, Cartels of the Mind, p. 49.

62 ibid., p. 54.

63 ibid., p. 54.

64 'Jānarisuto haiso kakutei'

65 McCargo and Lee, 'Japan's Political Tsunami', p. 242.
} 
damaged by the earthquake and tsunami in March 2011), freelance journalists were not allowed to use camera equipment, even though cameras were allowed for corporate media. ${ }^{66}$

Unfortunately, 'The most important news normally originates in the relaxed, homey setting of the kondan background sessions.' ${ }^{37}$ Furthermore, McArthur argues, 'There is very little attempt to discuss the controversy in terms other than those supplied to the press at government and industry briefings, a phenomenon symptomatic of the close relationship between [the] reporters' club and the bureaucracy.' ${ }^{68}$

While Japanese officials claim that all information and handouts are given to nonmembers upon request, this process takes time. On the other hand, regular club members automatically receive information that can be delivered to the public directly. Japanese corporate newspaper journalists have a huge fear of missing out on a story, and feel safe and comfortable when their articles are just the same as others. ${ }^{69}$ This further helps explain why most Japanese whaling articles are a reflection of the government's voice.

The kisha club system raises questions about whether it is possible to have independent reporting within the Japanese media environment. However, making a moral judgement is fraught with difficulty, and according to the well-known philosopher James Rachels and his son Stuart Rachels, when people begin to develop theories of right and wrong, 'the protection of their own interests has a kind of ultimate and objective value. ${ }^{70}$ This could explain why both Australian and Japanese journalists produce biased articles, as this study reveals. However, ethicists including Rachels and Rachels maintain that respect should not be limited to a particular race, nationality, gender or even species. ${ }^{71}$ Media ethics specialist Ian Richards says, "telling the truth" means reporting diverse opinions rather than just one.72 He also says, "journalists strongly emphasise the need for the highest degree of accuracy to keep faith with their audience. ${ }^{37}$

Journalism ethics is a relatively new field of study, especially in Japan. In the article Social Responsibility Theory and the Study of Journalism Ethics in Japan, Seijiro Tsukamoto explains that journalism ethics is rarely discussed in academic journals. ${ }^{74}$ Additionally, even though 199 Japanese universities and colleges have courses related to mass communications, only 21 of those offer courses in ethics. ${ }^{75}$ However,

\footnotetext{
66 Segawa, 'Reporters Without Borders on Discrimination Against Freelance Journalists in Japan'.

67 Hall, op. cit., p. 54.

68 McArthur, op. cit., p. 585.

69 Tsujii, 'Ima, seiken kōtai no imi wo aratamete tou', p. 79; Aiba, “Kiji copī” wa nichijōsahanji'.

70 Rachels and Rachels, The Elements of Moral Philosophy, p. 174.

1 ibid., p. 181.

Richards, Quagmires and Quandaries, p. 21.

ibid., p. 5.

Tsukamoto, 'Social Responsibility Theory and the Study of Journalism Ethics in Japan', p. 56.

75 ibid., p. 57.
} 
universities and colleges should not be seen as solely responsible. He also says, 'mass media companies do not have high expectations of journalism ethics education. ${ }^{36}$

The ethical problem in journalism is not unique to Japan. Richards says that in Australia, 'Journalism ethics has been largely ignored'. ${ }^{77}$ In Australia, as recently as the

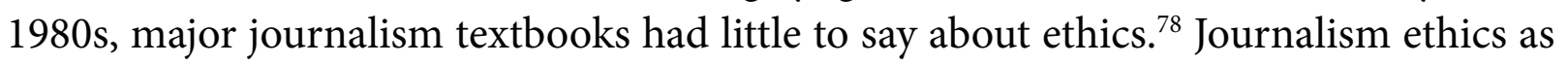
studied by journalists has produced insufficient outcomes, and Richards states that no philosopher has conducted a serious study on the subject. ${ }^{79}$

However, this is no excuse for journalists to rest on their laurels. Media is not just a source of information, but also plays an important role as an educator. On international events such as whaling, journalists need to expand their views beyond the domestic situation, otherwise people are not given the information they require in order to understand their civic duties in today's global village. People ought to learn something new from media, but unfortunately, the current reports on whaling both in Australia and Japan are too nationally biased to convey quality information, thus threatening to worsen this international conflict.

Media services should not be limited to one's own community or country; instead, journalists ideally should work to meet the 'needs of world citizens.' ${ }^{\text {'0 }}$ With the development of communication technologies, the emotional and informational distance between any two countries is getting shorter. More and more people across the planet are identifying with the concept of cosmopolitan world citizens. As these global movements continue, journalism too needs to become more globalised in order to reflect the common interests of this world citizenry, which at a most fundamental level includes an interest in promoting peace and conflict resolution. To this end, reporting should offer comprehensive views that develop mutual understanding, rather than reinforcing simplistic domestic positions.

\section{Conclusion}

This study has identified that both Australian and Japanese journalists produce nationally biased news stories. In particular, corporate Japanese journalists are tied to the kisha club, where they are provided with privileged information by the Japanese government

\footnotetext{
76 ibid., p. 58.

77 Richards, op. cit., p. 1.

78 ibid., p. 15.

79 ibid., p. 2.

80 Ward, 'Philosophical Foundations for Global Journalism Ethics', p. 16.
} 
which justifies Japanese whaling as scientific according to international regulations. This paper has not included a comparative explanation of Australian reporting. This matter is outside of the scope of this paper, but selected articles have already been used for discourse analysis following the content analysis. The discourse analysis is modelled upon Murata's earlier study ${ }^{81}$ and its findings revealed the shortcomings of Australian reporting. The discourse findings will be addressed later in a forthcoming publication. Nevertheless, the content findings in this study have revealed how both Australian and Japanese journalists misrepresent the intricacies of the whaling issue. In this sense, their reporting does not provide sufficient cultural and political transparency to contribute to international and cross-cultural understanding.

81 Murata, op. cit. 


\section{New Voices Volume 6}

\section{Reference List}

'A Whaling State of Mind', The Age, 16 January 2007. Retrieved 29 November 2012, from http://blogs.theage.com.au/ yoursay/archives/2007/01/a_whaling_state.html?page=fullpage\#comments.

Aiba, H., “Kiji copi”” wa nichijōsahanji: Masukomi no nekko ni hisomu yami towa' [“記事コピー”は日常茶飯事…… マスコミの根っこに潜む闇とは], Business Media Makoto, 28 June 2012. Retrieved 30 June 2012, from http://bizmakoto.jp/makoto/articles/1206/28/news002.html.

'Antarctica Law \& Government', Law Research. Retrieved 4 December 2012, from http://www.lawresearch.com/v2/ global/zaq.htm.

Arai, S., 'Nihon no chōsa hogeisen ni sōgyō teishi meirei, gōrenpōsai' [ 日本の調査捕鯨先に操業停止命令 豪連邦 裁], Yomiuri Shimbun, 16 January 2008, p. 2.

Arai, S., 'Hogei no shōko shūshū: Gō kanshisen ga shukkō’ [捕鯨の証拠収集 豪監視船が出航], Yomiuri Shimbun, 10 January 2008, p. 2.

Arai, S., 'Nankyokukai deno nihon no hogei, gō ga kanshi e’ [南極海での日本の捕鯨、豪が監視へ], Yomiuri Shimbun, 8 January 2008, p. 2.

Arai, S., 'Nihon no hogei, Ōsutoraria ga kanshi e’ [日本の捕鯨活動、オーストラリアが監視へ], Yomiuri Shimbun, 20 December 2007, p. 2.

Cave, P., “Bukatsudō”: The Education Role of Japanese School Clubs', Journal of Japanese Studies, vol. 30, no. 2 (2004), pp. 383-415.

Cunningham, P. et al., 'From Whaling to Whale Watching: Examining Sustainability and Cultural Rhetoric', Journal of Sustainable Tourism, vol. 20, no. 1 (2012), pp. 143-161.

Eco, U., Mouse or Rat? (London: Orion Books, 2004).

'Dai ni ki nankyokukai geirui hokaku chōsa (JARPAII): 2007/08 nen (dai san ji) chōsa kōkai no chōsa kekka ni tsuite [第二期南極海鯨類捕獲調査(JARPAII)－2007/08年(第三次)調査航海の調査結果について一]', The Institution of Cetacean Research, 14 April 2008. Retrieved 4 December 2011, from http://www.icrwhale.org/ 080414ReleaseJp.htm.

Danaher, M., 'Why Japan Will Not Give Up Whaling', Pacifica Review, vol. 14, no. 2 (2002), pp. 105-120.

Davis, R., 'Taking on Japanese Whalers: The Humane Society International Litigation', University of Tasmania Law Review, vol. 24, no. 1 (2007), pp. 78-86.

Gales, N. et al., 'Japan's Whaling Plan under Scrutiny', Nature, vol. 435 (2005), pp. 883-884.

‘Gō no hogeisen sōgyō teishi meirei, Machimura kanbō chōkan 'eikyō nai’ [豪の捕鯨船操業停止命令 町村官房長官 「影響ない」], Yomiuri Shimbun (Evening Edition), 16 January 2008, p. 14.

Hall, I., Cartels of the Mind: Japan's Intellectual Closed Shop (New York: W. W. Norton, 1998).

Hartley, J., Understanding News (London: Routledge, 1982).

Herrscher, R., 'A Universal Code of Journalism Ethics: Problems, Limitations, and Proposals', Journal of Mass Media Ethics, vol. 17, no. 4 (2002), pp. 277-289. 
Hirata, K., 'Why Japan Supports Whaling', Journal of International Wildlife Law and Policy, vol. 8 (2005), pp. 129-149.

Hoshikawa, J., ‘(Watashi no shiten waido) Chōsa hogei: Kansei jōhō wo hanare kokueki handan wo’ [ (私の視点ワイ ド）調査捕鯨 官製情報を離れ国益判断を], Asahi Shimbun, 31 August 2008, p. 15.

Huntington, S., The Clash of Civilizations and the Remaking of World Order (New York: Simon \& Schuster, 1996).

Ishii, A. and Okubo, A., 'An Alternative Explanation of Japan's Whaling Diplomacy in the Post-Moratorium Era', Journal of International Wildlife Law and Policy, vol. 10, no. 1 (2007), pp. 55-87.

'Jānarisuto haiso kakutei...Kisha kurabu igai wa haijo’ [ジャーナリスト敗訴確定…記者クラブ以外は排除], Sankei Shimbun, 9 May 2009, p. 25.

Kimura, T., ‘Gōshūjin wa naze hogei ni hantai suruka’ [豪州人はなぜ捕鯨に反対するか], Mainichi Shimbun, 2 April 2011, p. 11.

Kimura, T., 'Seifu ga hogei haishi motome ICJ ni teiso: Maketara kirifuda wo ushinau tono hihan mo' [政府が捕鯨廃 止求めICJに提訴 負けたら切り札を失うとの批判も], Shukan Kinyōbi, 11 June 2010, p. 12.

Kimura, T., 'No Legal Enforcement Can Stop Japan's Whaling: Will the Whaling War Ever End?', Tokyo Work Life, 1 December 2009. Retrieved 1 December 2009, from http://www.tokyoworklife.com/column/country/australia/ no-legal-enforcement-can-stop.html.

Kimura, T., 'New Strategy Needed for Elusive Quarry', The Age, 11 January 2008, p. 11.

Kimura, T., 'A Cool Head Required to Save the World's Whales', The Canberra Times, 5 June 2007, p. 11.

Kimura, T., 'Lost in Translation', The Press (Christchurch, 13 March 2007), p. A9.

Kimura, T., 'Why Japan is Deaf to Whaling Protests', The New Zealand Herald (Auckland, 12 March 2007), p. A13.

Kimura, T., 'Nihon seifu no atsuryoku ni Kōdansha wa kusshita, chosho "Purinsesu Masako" hōyaku shuppan chūshi de Hiruzu-shi’ [「日本政府の圧力」に講談社は屈した 著書「プリンセス・マサコ」邦訳出版中止 でヒルズ氏], Nikkan Berita, 17 February 2007. Retrieved 29 June 2012, from http://www.nikkanberita.com/ read.cgi?id=200702171324256.

Kimura, T., 'Getting to Know the Japanese', The Age, 16 January 2007, p. 11.

McArthur, I., 'Media Portrayal of the Cultural Relationship between Australia and Japan', Australian Journal of International Affairs, vol. 60, no. 4 (2006), pp. 574-589.

McCargo, D. and Lee, H., 'Japan's Political Tsunami: What's Media Got to Do with It?', The International Journal of Press/Politics, vol. 15, no. 2 (2010), pp. 236-245.

Meaney, N., Towards a New Vision: Australia and Japan through 100 Years (East Roseville: Kangaroo Press, 1999).

Murata, K., 'Pro- and Anti-whaling Discourses in British and Japanese Newspaper Reports in Comparison: A Crosscultural Perspective', Discourse and Society, vol. 18, no. 6 (2007), pp. 741-764.

Rachels, J. and Rachels, S., The Elements of Moral Philosophy (6th ed.) (Boston: McGraw-Hill, 2010).

Regan, T., All That Dwell Therein: Animal Rights and Environmental Ethics (Berkeley: University of California Press, 1982).

Richards, I., Quagmires and Quandaries: Exploring Journalism Ethics (Sydney: University of New South Wales Press, 2005). 
New Voices Volume 6

Rudd, K., 'Media Release: Visit to Japan and Indonesia', Australian Government Media Release, 23 May 2008. Retrieved 30 August 2009, from http://www.pm.gov.au/node/5781.

Segawa, M., 'Reporters Without Borders on Discrimination Against Freelance Journalists in Japan’ [国境なき記 者団、日本におけるフリーランス・ジャーナリストに対する差別的対応を批判], The Asia-Pacific Journal: Japan Focus, 3 June 2012. Retrieved 29 June 2012, from http://www.japanfocus.org/events/view/150.

Singer, P., 'Hypocrisy Weakens West's Whaling Protests', The Japan Times, 17 January 2008, p.15.

Singer, P., How Are We to Live? (Milsons Point: Mandarin, 1993).

Singer, P., 'Why the Whale Should Live', Habitat Australia, vol. 6, no. 3 (1978), pp. 8-9.

Smith, S. and Garrett, P., 'Return of Japanese Whaling Fleet to Port', Australian Government Media Release, 15 April 2008. Retrieved 10 September 2009, from http://www.environment.gov.au/minister/garrett/2008/pubs/ mr20080415.pdf.

Sugii, A., ‘Chōsa hogei shūgeki niwa hinan, “sōhō jisei wo” gō sumisu gaishō’ [調查捕鯨襲撃には非難、「双方自制 を」豪・スミス外相], Asahi Shimbun, 4 March 2008, p. 35.

Sugii, A., 'Hogeisen, NZ kinkai e: Toraburu wo dannen' [捕鯨船、NZ近海へトラブルを断念], Asahi Shimbun, 26 January 2008, p. 37.

Sugii, A., ‘Gō, nihon no chōsa hogei kanshi: Hozon katsudō e hōtei tōsō mo’ [豪、日本の調査捕鯨監視 保存活動 法廷闘争も], Asahi Shimbun, 20 December 2007, p. 7.

Tsujii, T., 'Ima, seiken kōtai no imi wo aratamete tou: Watakushitachini hitsuyōna shiten towa' [いま、政権交代の意 味を改めて問う 私たちに必要な視点とは], Sekai, vol. 810 (2010), p. 79.

Tsukamoto, S., 'Social Responsibility Theory and the Study of Journalism Ethics in Japan', Journal of Mass Media Ethics, vol. 21, no. 1 (2006), pp. 55-69.

van Wolferen, K., 'The Japan Problem', Foreign Affairs, vol. 65, no. 2 (1986), pp. 288-303.

Ward, S., 'Philosophical Foundations for Global Journalism Ethics', Journal of Mass Media Ethics, vol. 20, no. 1 (2005), pp. 3-21.

Wallace, R., 'Japan Tech Deal could Help Power our Subs', The Australian, 27 September 2012, p. 2.

'Whalers guarded', The Advertiser, 30 January 2008, p. 30.

Wong, A., The Roots of Japan's Environmental Policies (New York: Garland Publishing, 2001).

Note: All Japanese newspaper articles in the reference list are from the main morning editions unless otherwise stated. 